\title{
Consumers Mobile Phone Brand Preferences of Local Made Brands to Global: Evidences from West Shoa Zone, Oromia Regional State, Ambo Town, Ethiopia
}

\author{
Negash Geleta \\ Lecturer of Ambo University in College of Business and Economics \\ Department of Management \\ P.O. Box: I9, Ambo University, Ethiopia \\ E-mail kenu2002@gmail.com
}

\begin{abstract}
The study was conducted in Oromia regional state West Shoa Zone in Ambo Town in case of "Consumer The mobile phone Brand Preferences of Local Made Brands to Global". Mobile phones are today can be considered as one of ingredient in the life of human beings. But due to rapid developments in technology, modernization and new innovations, there is a short lifecycle of mobile phone, which has a great impact on the manufacturers and retailers of such products. Then this study aimed to investigate the factors effecting consumers Mobile brand preferences local to global. The study employed both descriptive and explanatory research design. The target populations of the study were the mobile phone users in Ambo town of West Shoa Zone Oromia regional state, Ethiopia. The data was collected from 385 respondents by using convenience sampling technique. For data analysis descriptive (mean $\&$ standard deviation) and inferential ( $t$-test, correlation analysis, and multiple regressions) were employed. Based on analysis the result shows the significance difference of local brand \& global. In addition the result of regression shows all variables statistically significant except innovation, social status, and price. This was because consumers were not affording imported brands. Then, it can be concluded that there was a significant relationship between consumers local brand preference and global. Therefore, it can be recommended that marketers should sell innovative brands to satisfy the desire of consumers.
\end{abstract}

Keywords: Consumer Preference, Brand, Mobile Phone, Local and Global.

\section{I.I. Background of the Study}

Consumer brand preference is an essential step in understanding consumer brand choice. Horsky et al. (2006) demonstrate the importance of incorporating information about brand preference into the brand choice model. Brand preferences represent consumer dispositions to favor a particular brand (Overby and Lee, 2006). It refers to the behavioral tendencies that reflect the extent to which consumers favor one brand over another (Hellier et al., 2003; Zajonc and Markus, I980). In the marketplace, consumers often face situations of selecting from several options (Dhar, 1999). It is also the element of relationship between company and customers (Kotler \& Armstrong, 2010). Globalization is an inevitable phenomenon that is leading the entire world towards becoming one market that is a global village (Holt, 2002). With the world becoming a single market, globalization has had a major contribution in enabling the organizations worldwide to step out of the restricted domestic markets and to set up their operations across the globe with confidence. The development of mobile communication technology e. g. wireless internet, mobile phone, MP3 player, GPS navigation system has been a long journey of innovation, which is constantly evolving and updating as a result of consumers changing needs and preferences (Mokhlis, S. \& Yaakop, A.Y. 2012). A study which investigates the consumer brand preference towards mobile phones by factor analysis method could remedy for the situation (Mokhlis, S. \& Yaakop, A.Y. 2012). The industry is very dynamic and new models are introduced to the market almost on a weekly basis. Availability of $3 \mathrm{G}$ and $4 \mathrm{G}$ networks and evolution of smart phones have made mobile phones more of a personal digital assistant. Beyond voice, the major trends shaping the mobile culture have been identified to be communication services such as voice, text and pictures; wireless internet services such as browsing and e mail and different media services such as motion pictures, games and music (Hossein, R. D. and Hamed, D. 2012). These studies indicated a range of items as a determinant factor influencing purchase decision such as price, features, quality, brand name, durability, social factors and so on (Li, 20I0). Mobile penetration in Ethiopia is very low when compared to the other African countries (Research ICT Africa, 20I0). However, there are a million the mobile phone subscribers owning various brands of mobile phone. During the mobile phone buying decision process, these subscribers' takes into account numerous factors. However, researchers devoted little attention to factors underlying the the mobile phone buying decision process in Ethiopia. This study seeks to know the factors that underlying a person's decision in choosing brand of mobile phone(s) to use. 


\section{I.2. Statement of the Problem}

With the advent and rapid growth of the technological era, the demand for mobile phones has increased (Petruzzellis, 20I0). Mobile phones are useful for communication, and are convenient for all users. Mobile phones are now a necessity in the lives of people. Due to rapid developments in technology, modernization and new innovations, there is a short the mobile phone lifecycle, which has a great impact on the manufacturers and retailers of such products (Henderson, 20I2). Manufacturers are forced to upgrade and design new models of mobile phones on an ongoing basis. However, the rapid introduction of cheaper versions of mobile phones in the world market especially in developing country such as Ethiopia may increase the rate of competition between companies (local and foreign) mobile industry. It is worth noting that many studies have been conducted in the area of brand preference and mobile phones across the world. Nevertheless, previous studies conducted by Petruzzellis (2010), Bhukya and Singh (2013), Shahzad and Sobia (2013), Karjaluoto, Karvonen, Kesti, Koivumaki, Manninen, Pakola, Ristola and Salo (2005), and Dadzie and Boachie-Mensah (20II) do not provide a common answer regarding the factors that influence brand preferences. But all these studies conducted in other counties not in Ethiopia especially not in the Ambo Town Given also that most studies were conducted in other countries, the findings do not exactly reflect the situation in the market, which therefore leaves a gap with regard to brand preference on mobile phones in the market. The invention of phone had put a slow death on other mobile, especially to infant countries such as Ethiopia, as trend of having the mobile phone is high. As detailed in the literature review more consumers consider quality, country of origin, price, social status, friends and family, user friendliness, innovation, brand image, promotions, celebrity endorsement and post purchase services to purchase a given the mobile phone based on the different studies conducted in different countries, but still no more studies in Ethiopia which shows the as the presence of the gaps. This implies the Ethiopian mobile factors have no the concept of its consumers presence of the brand made in Ethiopia/locally made brands over imported once. Thus this study was try to explore and gain a clear understanding of the factors that influence brand preferences of consumers' domestic and foreign the mobile phone in the Ambo Town

\section{I.3. Objective of the Study}

- To assess factors affecting consumers' preference of local made the mobile phone brands to global.

- To examine the level of factors affecting consumers' preference of local mobile brands to global.

\subsection{Significance of the Study}

The study may provide new insights for local producers and sellers of the mobile phone brands. In detail it my benefit manufacturers producing new brands of mobile phones, develops insights whether there is any preference for factors affecting consumer preference between local and international brands and it help marketers to identify and adopt the best ways to building brand image for consumers. Further this study may improve brand image in turn, increase demand for the local brands and increase premium income generation and contribution to the economy of the country. Additionally, this study might be used as a baseline and serve as a reference for those who want to conduct further investigation in this area.

\section{Related Literature}

\section{I. Concept of Brand}

A brand can be defined as "a name, term, sign, symbol, or design, or a combination of them, intended to identify the goods and services of one seller or group of sellers and differentiate them from those of competitors (American Marketing Association, 1997). Consumers use brands as cues to make decisions to purchase or try products (Ger et al., I993). According to Nicholas Ind (1997), brand can be described as a feature of a plain idea of product or service, and it includes the definition or a view of the values that go deeper in the functional performance. In the other words, "A product is something that is made, in a factory; a brand is something that is bought by a customer." Aaker (I99I) noted that the brand signals the source of the product to consumers, and protects the customer, as well as, the producer from possible competitors who would attempt to provide products that appear to be identical. Consumers remain committed and loyal to a brand as long as they believe and have an implicit understanding that the brand will continue meeting their expectations and perform in the desired manner consistently.

2.2. Brand Preference: The notion of preference has been considered by different disciplines, such as economists (e.g. Samuels, 1978), psychologists (e.g. Albanese, 1987) and sociologists (e.g. Tomer, I996). However, there is no commonly-agreed definition of preference among these disciplines. For example, economists state that preferences are exogenous, stable, known with adequate precision and are revealed through choice behavior (March, 1978, p.589). The economic view of preference was criticized for assuming that preferences are stable and endogenous. An individual's preferences are not stable (Albanese, I987) and can be endogenous or exogenous (Samuels, 1978). In marketing, the concept of preference means the desirability or choice among alternatives (Oliver and Swan, 1989). While Zajonc and Markus (1982, p. 128) propose that "a preference is a 
behavioral tendency that exhibits itself not so much in what the individual thinks or says about the object, but how he acts toward it", Tomer (1996) differentiates between four types of consumer preferences; the actual preference is the degree to which the consumer appreciates and develops the capacity to use certain goods. Meta-preferences are one's preferences about actual preferences that reflect the normative judgments of the higher-order self (meta-self). True preferences are a unique set representing what is really and truly the best for the person. Finally, unrestrained preferences are those that satisfy the lower or physical needs. The individual's preferences are determined by his or her actual preferences that reflect the meta-preferences and unrestrained preferences. In marketing literature, there are numerous definitions for brand preference.

\subsection{Factors Affecting Consumers Brand Preferences}

2.3.I. Quality: Perceived quality is defined as the consumers' judgment about an entity's (service's) overall excellence or superiority (Zeithaml, 1988 and Rowley, 1998). Research also indicates that consumers value global brands especially for their assumed high quality and prestigious image (e.g., Nguyen, Barrett and Miller 2005; Steenkamp, Batra and Alden 2003). An internationally well-established brand name can act as a "halo" constructs that effects quality beliefs (Han I989). If a brand is perceived as globally available, consumers are likely to attribute a superior quality to the brand, since such quality is thought of as a prerequisite for international acceptance. Product Quality indicates the extent to which product is carrying out its desired work \& this is treated as an important factor which influence the brand choice (Khan \& Rohi, 2013). Quality can also be defined as the difference customer observes in actual level of performance in comparison to the perceived level of performance (Kang, 2006). Research conducted in India indicated that unbranded products vary significantly in their quality dimensions therefore people perceive something as a brand only because of its better quality. Moreover research also indicated that aesthetics and quality of product are the two main components which differentiate successful brand from unsuccessful brand (Sardar, 2012). While according to research work of 2013 brand quality is an element which influences the purchase behavior of customer and it is essential to make a brand comprehensive one as compared to the competing brands, especially when it faces competition from well known brands of the world(Arif, Ahmed \& Farrukh, 2015) \& (Piktumiene, 2013). Moreover consumer also holds perception associated with quality and safety which also affect their buying decision, but both quality and safety are treated as those variables which are very hard to define and consumers are force to evaluate quality as well as safety of the products on the basis of other signals associated with products whether intrinsic, like product appearance or external like its label and associations (Nelson, 1970). Research work conducted in the year 2014 proves that youth is treated as the part of Generation Y therefore they always preferred those products which are technologically sound and the major reason behind their preference is that they have innovative nature and therefore always inclined towards those products which will provide better incident. While the other research work indicated that quality of product results in formation of durable and satisfactory relationship with the company. Furthermore research conducted in 2014 also emphasized upon the requirements of quality in order to create the desired impact of youth of Pakistan (Awan \& Faima, 20I4)

2.3.2. Country of Origin: The country of origin effect has been defined as "the positive and negative influence that a product's country of manufacture may have on consumers' decision making processes or subsequent behavior (Elliott and Cameron, 1994). 199I). In fact in the words of Nagashima (I970), COE can be defined as "the picture, the reputation, and the stereotype that businessmen and consumers attach to products or brands of a specific country. This image is created by such variables as representative products, national characteristics, economic and political background, history, and traditions". The literature on country-of-origin effects is quite rich and covers the topic from different perspectives in different countries. Some studies have shown that country of origin also has symbolic and emotional meaning to consumes, and it plays an important role along with other attributes such as quality and reliability in shaping consumers attitudes toward products. Moreover, attitudes and perceptions of consumers toward brands and products will depend on categories, for instance, electronic goods from Italy may be perceived as a poor quality but Italian clothing would be perceive as fashionable and high quality (Bikey and Nes, I982). This would be differently perceived with Japanese brands as Japanese electronic goods would be perceived with positive attitudes and Japanese clothing was negatively perceived. A key determinant of consumers ee perceptions, evaluations, and purchase intentions for consumer goods is the concept of Country-of-Origin (COO). The concept of country of origin, according to Usunier (2006), has become one of the most researched international aspects of consumer behavior. In years past, attempts have been made to examine the effect of $\mathrm{COO}$ in various spheres of life. Hamzaoui and Merunka (2006) observe that the kind of beliefs that consumers have and how they perceive different countries affects their purchase evaluations. Results of studies by Agbonifoh and Elimimian (1999) and Olaleke (2010) in Nigeria as well as Opoku and Akorli (2009) in Ghana, show that products from technologically advanced countries were viewed more positively by consumers of developing countries than their counterparts in the advanced economies. Opoku and Akoril (2009), Olaleke (2010) and Saffu and Walker (2006), in examining the impact of $\mathrm{COO}$ on consumers ${ }^{e e}$ attitudes towards buying local campaign initiatives, found that the attitudes of consumers can be seen as protectionist, nationalistic and of self-interest. The above empirical evidence, though not exhaustive, suggests that consumers in developing economies, of which Nigeria is one, view products from developed countries more 
favorably than products from their own country. However, the direction of this influence needs to be verified in Nigeria in the area of patronage of consumer goods, hence the need for this study.

2.3.3. Price: Researchers found out that once consumers perceive a price difference between local-owned and foreign owned brands, price dissimilarities begin to affect their preference for local-owned brands. Therefore, since price is also one of the most important extrinsic cues that consumers use when evaluating the product/brand (Hansen, 2005), we test the impact of price against consumer's ethnocentric tendencies to determine at what point consumers are willing to forsake preference for local products for a greater price discount with foreign owned products. This variable has a significant impact on consumer buying behavior and because of its importance we can easily state that price is treated as single and most critical factor which can cause determinant on consumer decision making and hence can significantly impacts the entire purchase process. Similarly, for youth, price might be treated as the most impactful factor (Khan \& Rohi, 2013). Moreover marketers might vary prices by considering economic situation prevailing in the location and might also consider perception of the target market, as it might result in change in the determination of customer perceived value and this change in perception is always critically important in the consumer's purchase decision. (Nilson, 1998 \& Kotler \& Amstrong, 1989) research conducted in order to examine the preference of youth found that the price has no association with the purchase preference of youth \& they mostly pay preference to factors and young consumers are not reluctant in paying more for the enhanced quality and features(Osman, Talib, Sanusi, Shiang \& Alwi, 20I2). But the research of 2014 provides conclusive evidence which proves that price is the significant factor for youth and definitely affects the buying preferences as they have limited resources and major source of their income is the pocket money given by their parents. Moreover the research also proves that companies which adapt low pricing strategies without compromising on quality of their offerings became able to create positive influence on the buying behavior of youth (Awan \& Fatima, 20I4).

2.3.4. Social status: Social classes are relatively standardized and stable divisions within societies made up of members who share the same principles and behaviors. Social classes possess different characteristics which allow for differentiation between them (Kotler and Keller 2009:193). According to McDaniel et al. (2012:204), social classes are groups of people who are similar in their behaviors and statuses, and who regularly socialize amongst themselves, both formally and informally. Upper class consumers usually prefer reading magazines and books, whilst lower class consumers prefer watching television (Kotler and Keller 2009:194). Consumers differ in their lifestyles due to their social statuses, for example when an individual is a professional post-graduate, their preferences was different from those of undergraduates (Schiffman and Kanuk 20I0:285). The authors cited agree that social classes are influential on the types of mobile phones that students prefer. This is because students wish to communicate certain social class statuses to those around them. Authors have stressed that consumers may prefer global brands because of associations of higher prestige (Schuiling \& Kapferer, 2004; Shocker, Srivastava, \& Rueckert, 1994; Steenkamp, et. al., 2003).

2.3.5. Friends and family: Reference groups include groups or people whom one can look up for guidance and ask for opinion. These are important source of influencing the brand purchases. Reference group include friends and family who influence ones buying decisions due to special skills, knowledge, personality. If a friend had a bad experience with a product, it is more likely that one will refrain from buying it. However many studies found out that, knowledge that consumers obtain through direct personal experience was perceived to be more trustworthy than information from other communications. Recommendations from family and friends is also treated as the factors which now becomes significantly important in creating impact on brand choice and purchase decision(Khan \& Rohi, 20I3). Research work carried out in early seventies proves that presence of family $\&$ friends create enormous impact on the brand choice, when they are with the consumer at the time of purchase (Asch, I95I \& Venkatesen, 1973). Furthermore research conducted in late nineties also indicated that liking of friends is a factor which can affect the selection of brand (Schiffman \& Kanuk, I997). Research work conducted in 2013 also pointed out the importance of social influence on the level of dependency of students and shows that they are highly dependent upon it in case of smart phones (Suki \& Suki, 2013). While research conducted in Kota city of India also supported the findings of Suki \& Suki and indicated that $36 \%$ of youth is influenced by their friends and made their purchase decision according to it (Upadhyay \& Joshi, 20I4).

2.3.6. Innovation: One of the basic method company uses to differentiate its offerings with respect to competitors is known as Innovation, Using Innovation also help company is matching its offering with the recent requirements of their customers. Therefore it is feasible to state that innovation is not only helps company in surviving during intense competition but also helps in developing unique position and image in against of competing ones (Khan \& Rohi, 2013). As the research conducted in 2015 highlighted that prefer those smart phones which have advanced features and on their purchase decision is heavily dependent upon these additional features (Kushwaha, 2015). Findings of research also indicated that innovation influences the process of research associated with marketing \& marketing researcher and they also tried to find out the process of adoption of these 
products (Saaksjarvi, 2003). Moreover research findings also indicated that for student's the most important factors is innovative features and this can significantly influence their buying behavior (Liu, 2002 \& Karjaluoto et al., 2005). While the research work of 2012 also emphasized on the importance of innovation and showed that innovation is one of the most influential factor for future use of smart phones and it is contributing up to $34 \%$ in the preference of consumers for future use (Enterprise News, 2012).

2.3.7. Brand Image: Research work conducted in the year 2010 explored the association between brand image and customer loyalty by taking reference of customers of Toyota Car and found that that there is a significant relationship between brand image \& loyalty. While the research conducted in 2013 selected one hundred and fifty youngsters as the respondent indicated that there is a significant impact of bran image on brand loyalty (Saeed, Javed \& Lodhi, 20I3). While the other research of the same year explored the relationship between the brand image and purchase intentions of youngsters by taking the reference of fast moving consumer goods and also found positive results in this regards(Tariq et al., 2013). While the prior research work conducted in Gujranwala city 2012 also tried to explore the relationship among the customer satisfaction and brand image on brand loyalty by taking sample of 200 youngsters and found positive results for both of their major objectives (Durrani, Godil., Baig \& Sajid, 2015). According to other researchers proposed that brand image is the variable which can enhance the level of performance of business as better brand image always results in positive behavior of customer towards the particular brand (Malik et al., 2013). Moreover it has been also indicated by the research male customers have strong relationship with their preferred brands as compared to the female customers (Khan et al., 2012).

2.3.8. Promotions: Any method through which information is communicated to buyer in order to create profile of the brand or its values is known as promotion (McCarthy \& Pereault, I984). It includes various methods used for promotion like advertisements, sales promotion techniques, word of mouth referrals etc. Each and every type of promotional technique is used to develop long term \& stronger brand identity and also to make customer remind about their various offerings (Khan $\&$ Rohi, 2013). While this is also indicated by the research work conducted in Kota city of India that $30 \%$ of the youth \& their decision making is influenced by advertising (Upadhyay \& Joshi, 20I4). Vyas (2007) investigated sales promotion activities of six apparel stores in Ahmadabad market and compares them on various dimensions. It presents major findings and provides insights on consumer behavior.

\subsection{Conceptual Framework}

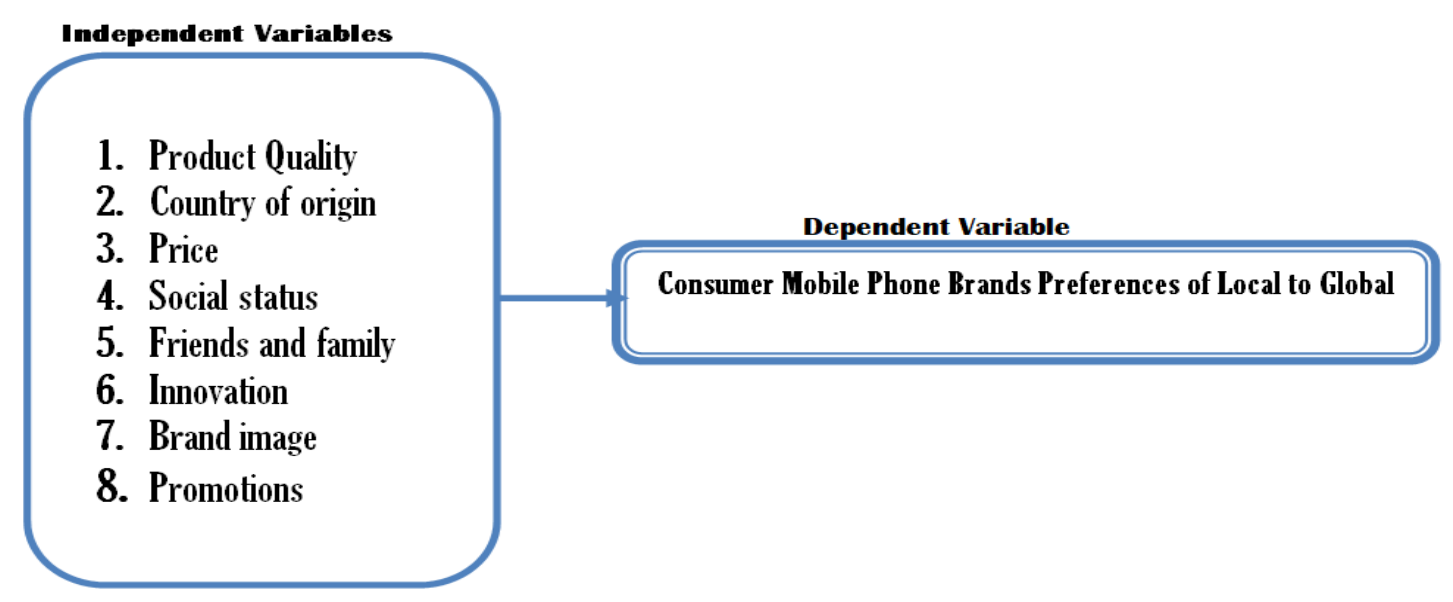

Source: Researcher Compilation from Literature

\section{Research Methodology}

3.I. Study Area: The study was conducted in Oromia region West Shoa Zone in Ambo Town Ambo town located atI I9KM West of Addis Ababa Capital city of Ethiopia.

3.2. Research Design: The study employed both descriptive and explanatory study design. Descriptive design was used to describe consumers' brand preference and explanatory study design was used for explaining, understanding and predicting the relationship between variables.

3.3. Data Sources: In this study, primary data was used. The primary data was collected from the users of local and global 
branded mobile phones from the Ambo Town

\subsection{Population, Sample size and Sampling Techniques}

The target populations for this study were the users of domestic and foreign branded mobile phones from the Ambo Town The study used 385 users of the the mobile phone based on Cochran (I963) to yield a representative sample for proportions/population. This method takes the value of $p=0.5$ in which case ' $n$ ' was the maximum and the sample was yield at least the desired precision. This is the most conservative sample size. The method takes an initial estimate of $p$ which may either be based on personal judgment or may be the result of a pilot study (Kothari 2004, P .I79). In this study the case was employed by using $\mathrm{p}$ and $\mathrm{q}=0.5$ which means equal proportion to use local or foreign brands since we have no clear cut proportion.

$\mathrm{n}=\frac{\left(Z^{2}\right) p . q}{\left(e^{2}\right)}=\mathrm{n}=\frac{\left(1.96^{2}\right) 0.5 * 0.5}{\left(0.05^{2}\right)}=385$

In order to identify the sample respondents from population, non-probability convenience sampling method was employed. As its name implies, convenience sampling is the collection of information from members of the population who are conveniently available to provide it. Such a contest, with the purpose of determining whether consumer prefer local brand to global, held at a shopping mall, on street and any place suitable for researcher.

3.5. Data Collection Instrument: The main instrument of data collection was questionnaire. The structured questionnaire was designed so as to make it easy to answer and to cover most of the common research questions. Furthermore, the questionnaire was designed so as to elicit information on both demographic and product use aspects of the respondents. In this research the questionnaire was pre-tested on a number of respondents who similar to those in terms of background characteristics in order to ensure that the instructions and the meanings of the questions must be simple, clear, unambiguous and beneficial to the subjects. The scores of response of the examinees to each item was calculated according to the five-point-scale, "Likert scale", strongly agree(5), agree(4), neutral(3), disagree(2) and strongly disagree(I).

\subsection{Variables and Model Selections}

Variables: The independent variables assumed for this study are quality, country of origin, price, social status, friends and family, user friendliness, innovation, brand image, promotions, celebrity endorsement and post purchase services. Dependent variable is consumer brand preferences (CBP) of mobile phone.

Model Specification: The equation of multiple regressions on this study is generally built around two sets of variable, namely dependent variables $\&$ independent listed below. Independent variables include quality, country of origin, price, social status, friends and family, innovation, brand image and promotions.

$$
\mathrm{CBP}=\alpha+\beta_{\mathrm{I}} \mathrm{X}_{\mathrm{I}}+\beta_{2} \mathrm{X}_{2}+\beta_{3} \mathrm{X}_{3}+\beta_{4} \mathrm{X}_{4}+\beta_{5} \mathrm{X}_{5}+\beta_{6} \mathrm{X}_{6}+\beta_{7} \mathrm{X}_{7}+\beta_{8} \mathrm{X}_{8}++\mathcal{E}
$$

Where:-

$>C B P$ is the dependent variable (consumer brand preferences)

$>X 1, X 2, X 3, X 4, X 5, X 6, X 7$ and $X 8$ are the explanatory variables.

$>\alpha$ constant term.

$>B I, \beta 2, \beta 3, \beta 4, \beta 5, \beta 6, \beta 7$ and, $\beta 8$ are coefficient of the variables.

$>\quad \mathcal{E}$ is error term.

3.7. Method of Data Analysis: To meet the specified research objectives quantitative data analysis was used for the study purpose. Both descriptive and inferential statistics methods of data analysis were employed. For running data SPSS V20 was employed. The descriptive statistical results were presented by using tables, mean, standard deviation and t-test. In addition Pearson's correlation coefficient was used to determine the relationships between independent variables and the dependent variable and finally multiple regression analysis was employed to examine the effect of the independent variables on consumer preference. 


\section{Result and Discussion}

\section{I. Respondents' Profile}

The demographic characteristics of the respondents include gender, age, level of education marital status , type of work, position in work place, and monthly income (in eth. birr).. The table below shows the details of characteristics of the respondents and their percentage.

Table 4.I: Respondents' Profile

\begin{tabular}{|c|c|c|c|}
\hline & Category & Frequency & Percent \\
\hline \multirow[t]{3}{*}{ I. Gender } & Male & 308 & 80.0 \\
\hline & Female & 77 & 20.0 \\
\hline & Total & 385 & 100.0 \\
\hline \multirow[t]{5}{*}{ 2. Your Age } & $20-30$ & $\mathrm{I} 44$ & 37.4 \\
\hline & $3 I-40$ & 164 & 42.6 \\
\hline & \begin{tabular}{|l|}
$4 \mathrm{I}-50$ \\
\end{tabular} & 43 & II.2 \\
\hline & Above 5I & 34 & 8.8 \\
\hline & Total & 385 & 100.0 \\
\hline \multirow[t]{6}{*}{ 3. Educational level } & High School & $4 \mathrm{I}$ & 10.6 \\
\hline & Diploma & I8I & 47.0 \\
\hline & $\mathrm{BA}$ & 104 & 27.0 \\
\hline & Masters & 43 & II.2 \\
\hline & Above Masters & 16 & 4.2 \\
\hline & Total & 385 & 100.0 \\
\hline \multirow[t]{3}{*}{ 4. Marital Status } & Single & 44 & II.4 \\
\hline & \begin{tabular}{|l|} 
Married \\
\end{tabular} & $34 \mathrm{I}$ & 88.6 \\
\hline & Total & 385 & 100.0 \\
\hline \multirow[t]{5}{*}{ 5. Type of Work } & Government & 79 & 20.5 \\
\hline & Private & 160 & 41.6 \\
\hline & Self & IIO & 28.6 \\
\hline & Unemployed & 36 & 9.4 \\
\hline & Total & 385 & 100.0 \\
\hline \multirow[t]{5}{*}{ 6. Monthly income (in Eth. Birr) } & I000-5000 & $\mathrm{I} 2 \mathrm{I}$ & 31.4 \\
\hline & $5001-10000$ & 126 & 32.7 \\
\hline & IO00I-I5000 & 65 & 16.9 \\
\hline & Above I5000 & 73 & 19.0 \\
\hline & Total & 385 & 100.0 \\
\hline \multirow[t]{3}{*}{ 7. Which Mobile brand you have preferred? } & Local & II7 & 30.4 \\
\hline & Global & 268 & 69.6 \\
\hline & Total & 385 & 100.0 \\
\hline
\end{tabular}

Source: Primary Data, 2020

In case of gender $80.0 \%$ of them were males and $20.0 \%$ were females. In terms of age, $37.4 \%$ of the respondents were $20-30$, $42.6 \%$ between 3 I-40 years, II.2\% were between 4I-50 years, and $8.8 \%$ were above 5I years. Respondents were also categorized based on the education level as shown in the table. The study revealed that $10.6 \%$ were high school, $47.0 \%$ were diploma holders, $27.0 \%$ of the respondents had BA, II.2\% had masters, and $4.2 \%$ had above masters. In terms of marital status $88.6 \%$ of the respondents were married and II.4\% of were single. Occupation-wise classification of the respondents infers that $20.5 \%$ of the respondents were government $41.6 \%$ private, $28.6 \%$ of the respondents were self and 9.4 percent of the respondents were unemployed. Monthly income of the respondents explores that $31.4 \%$ of respondents were earning the income ranges between 1000-5000, 32.7\% were earning between 500I-I0000 birr, and I6.9 \% were IO00I-I5000 and more than Above 15000 were only 19.0 percent. Finally as shown in table $69.6 \%$ of consumers' preferred global brand which means more consumers preferred global brand and the left $30.4 \%$ were preferred local brands. 
4.2. Descriptive Analysis of Factors Affecting Brand Preferences

Table 4.2 Descriptive Analysis of Factors Affecting Consumers Brand Preferences

\begin{tabular}{|c|c|c|c|c|c|}
\hline & Items & Mea & SD & $\mathrm{t}$ & Sig. \\
\hline \multirow{5}{*}{ 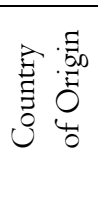 } & I. I usually prefer foreign brands (phone) than local. & 3.09 & .986 & 61.48 & .000 \\
\hline & 2. Local brands minimize fear over global. & 2.98 & I.00I & 58.44 & .000 \\
\hline & 3. I feel a risk of purchase local brands preferred to global. & 3.05 & I.II7 & 53.52 & .000 \\
\hline & 4. Perceived qualities of local phone match the actual quality. & 2.87 & 1.189 & $47.4 \mathrm{I}$ & .000 \\
\hline & 5. Local brand has more reputation than global. & 2.75 & I.I 42 & 47.23 & .000 \\
\hline \multirow{8}{*}{ 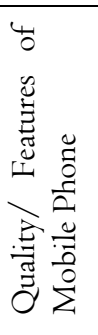 } & I. Local phone has more applications than foreign phone & 2.95 & 1.086 & 53.26 & .000 \\
\hline & 2. I prefer local phone based on the physical characteristics. & 2.80 & 1.040 & $52.8 \mathrm{I}$ & .000 \\
\hline & 3. Local brands' internet is speedier than foreign. & 2.74 & 1.060 & 50.77 & .000 \\
\hline & 4. I prefer local phone than foreign in case of durability. & $2.8 \mathrm{I}$ & I.I08 & 49.70 & .000 \\
\hline & 5. The bigger the size of the memory of the local the better. & 2.67 & .997 & 52.52 & .000 \\
\hline & 6. I consider quality of local the mobile phone branded is better. & 2.92 & .919 & 62.32 & .000 \\
\hline & 7. I consider reliability of the the mobile phone of local is better. & 2.92 & .919 & 62.32 & .000 \\
\hline & 8. Local phone features, and size influence the choice I make. & 3.00 & 1.048 & 56.15 & .000 \\
\hline \multirow{3}{*}{ च्व } & I. My friends' preference influence purchase of local phone. & 2.79 & I.106 & 49.48 & .000 \\
\hline & 2. My friends use local branded phone other than foreign. & 2.89 & 1.169 & 48.57 & .000 \\
\hline & 3. My friends influence my decision in buying local brand. & 2.73 & I.04I & 51.39 & .000 \\
\hline \multirow{3}{*}{ 莺密 } & 4. I collect local brand information from my family. & 3.01 & .933 & 63.23 & .000 \\
\hline & 5. My family recommends me to purchase local brand. & 2.96 & .915 & 63.55 & .000 \\
\hline & 6. I prefer the local brand because my friends use it. & 3.02 & 1.053 & 56.29 & .000 \\
\hline \multirow{6}{*}{ 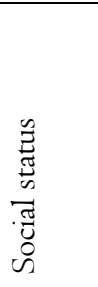 } & I. Local made phone has social pressure impact on my choice. & 2.84 & I.07I & 51.95 & .000 \\
\hline & 2. I purchase a brand if it fit my social group better. & 2.79 & I.106 & 49.47 & .000 \\
\hline & 3. Local brand influence other consumers' word-of-mouth. & 2.89 & I.I69 & 48.57 & .000 \\
\hline & 4. Local brand show my prestige of social class I prefer. & 2.73 & I.04I & 51.39 & .000 \\
\hline & 5. My social status more influenced by local branded phone. & $3.0 \mathrm{I}$ & .933 & 63.23 & .000 \\
\hline & 6. Local brands have a higher prestige than global brands. & 3.45 & 1.286 & 52.59 & .000 \\
\hline \multirow{2}{*}{$\begin{array}{l}\overrightarrow{\widetilde{w}} \\
\bullet\end{array}$} & I. I prefer local phone attributes than foreign. & 2.86 & 1.085 & 51.69 & .000 \\
\hline & 2. Portability of local phone brand is better than foreign. & 2.78 & 1.037 & 52.54 & .000 \\
\hline \multirow[b]{2}{*}{ సี } & 3. Transmission of mobile data is strong and stable. & 2.69 & 1.439 & 36.62 & .000 \\
\hline & 4. The coverage of mobile signal network is extensive. & 3.01 & 1.420 & 41.53 & .000 \\
\hline \multirow{4}{*}{ 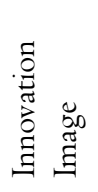 } & 5. I prefer local phone image than foreign. & 2.96 & 1.08 & 53.86 & .000 \\
\hline & 6. Local brand name can affect my decision. & 2.79 & 1.02 & 53.99 & .000 \\
\hline & 7. I purchase local brand, regardless of price. & 2.72 & 1.04 & $5 \mathrm{I} .45$ & .000 \\
\hline & 8. I choose local phone brand because it has a good reputation. & 2.89 & I.I5 & 49.44 & .000 \\
\hline \multirow{4}{*}{$\stackrel{\mathscr{U}}{\tilde{D}}$} & I. I prefer local phon & 2.95 & 1.09 & 52.99 & .000 \\
\hline & 2. Local brand name influences my decision to buy. & 3.01 & .933 & 63.23 & .000 \\
\hline & 3. I make purchase local phone brand, regardless of price. & $3.2 \mathrm{I}$ & 1.39 & 45.36 & .000 \\
\hline & 4. I choose local phone brand because price is faire. & 3.17 & I.39 & 44.63 & .000 \\
\hline \multirow[t]{8}{*}{ 岁 } & I. Local phone promotion is associated with my view & 2.75 & I.I0 & 48.99 & .000 \\
\hline & 2. Local brand of knowledge obtained through advertising. & 2.64 & 1.06 & 49.13 & .000 \\
\hline & 3. Local brand advertising influences my preference. & 2.57 & 1.06 & 47.44 & .000 \\
\hline & 4. Local brand promotions had an impact on my preference. & 2.58 & 1.10 & 46.00 & .000 \\
\hline & 5. Word of mouth had an impact on my local preference. & 2.44 & .99 & 48.27 & .000 \\
\hline & 6. I use catalogues when I choose a local phone brand. & 2.77 & .95 & 57.46 & .000 \\
\hline & 7. Sales promotion influences my local brand preference. & 2.79 & .95 & 57.44 & .000 \\
\hline & 8. Local brand promotion has strong brand identity. & 2.95 & I.05I & 55.01 & .000 \\
\hline
\end{tabular}

Source: Primary Data, 2020 
In table 4.2 the result of eight variables were summarized. The first was country of origin. As the result revealed, on item I which was "I usually prefer foreign brands (phone) than local" the highest mean was obtained that was 3.09. While, low mean was found on item 5 "local brand has more reputation than global" with the mean of 2.75 . The rests of items have lower mean which was less than 3 . This implies majority of the respondents disagreed that country of origin variable was not playing an important role in influencing preference of consumers' local mobile brand than global. Then according to this study consumer more prefer non-local brands than local. The standard deviations of each item also detected in the above table were almost similar. It means that the data of these items tend to be very close to the same value and data collected similar to one another. The t-test value of the country of origin variables is statistically significant at $5 \%$ level. Accordingly the $t$-values for all items were greater than the table value (1.96). Based on the result, it can be concluded that country of origin is influencing consumers to use global local made brands than local brands. The findings' of current study was consistent with some previous studies such as Agbonifoh and Elimimian (1999) and Olaleke (2010) in Nigeria as well as Opoku and Akorli (2009) in Ghana, show that products from technologically advanced countries were viewed more positively by consumers of developing countries than their counterparts in the advanced economies. The second variable was under qualities/ features which includes 8 items. Accordingly the first item revealed that the extent to which applications' of local made the mobile phone affects the preferences' of consumers than global brands. The mean score found was 2.95 which was lower than 3 . This indicates respondents were dis agreed as local brand application than that of global. Similarly, the mean of the statement measuring physical characteristics, internet accessibility durability, size of the memory, quality, reliability and size of brand as a factor with respect brand preference of users have mean values lower than 3 except item 8 . This indicates that most of the respondents agreed that these factors affect the brand preference of consumers. The significant value ( $p$-value) for all statements is 0.00 , which is less than 0.05 . This indicates that the statements are statistically significant. So far the t-values for all items were greater than the critical value (I.96). In addition this proves that there were significant differences between the two brands on its qualities/ features. So it can be concluded that local brands' qualities/ features mostly affect the preference of the consumers than global.

The third variable was friends and family with respect to six items. Based on the result, item six which was "I prefer the local brand because my friends use it" has the preferable mean than other items which was 3.02 and followed by the fourth item with mean 3.0I. While, the rests of 4 items have lower mean which is less than 3 . This means majority of the respondents disagreed that friends and family variable was playing an important role in influencing purchasing behavior of consumers' local mobile brand than global. Standard deviation measure/ indicate how data far/close to/from mean. Item 2 "My friends use local branded phone other than foreign has the highest SD=I.I69". This shows that the data of this item are spread/ apart to the large value and the data collected would not the same to one another. Next, the SD for I, 6 and 3 are I.I06, I.053 and I.04I respectively whereas item 5 has the lowest $\mathrm{SD}=0.9$ I5.It means that the data of this item tend to be very close to the same value and data collected would have the similar to one another. The t-test values of the friends and family variables are statistically significant at 5 percent level. This specifies that the items are statistically significant. Accordingly the t-values for all items were greater than the table value (I.96). As a result it can be concluded that friends and family are not influencing consumers to use local made brands than global since no more consumers using local brands. The fourth variable was social status. This variable is used to see the impact of social status on the local made mobile consumers' preferences. Accordingly the sixth item revealed that local brands have a higher prestige than global brands' with 3.45. Comparatively the low mean (2.79) score was found on item 2 "local brand show my prestige of social class I prefer". This indicates respondents were disagreed as local brand related to their social status than that of global. The significant value ( $\mathrm{p}$-value) for all statements is 0.00 , which is less than 0.05 . This indicates that the statements are statistically significant. So far the t-values for all items were greater than the critical value (I.96). In addition this proves that there were significant differences between the two brands on its qualities/ features. So it can be concluded that local brands' social status mostly affect the preference of the consumers than global that means no more consumers use local made brand as social status clue in the selected study areas. Authors have stressed that consumers may prefer global brands because of associations of higher prestige (Schuiling \& Kapferer, 2004; Shocker, Srivastava, \& Rueckert, I994; Steenkamp, et. al., 2003). Global brands may have a higher prestige than local brands due to their relative scarcity and higher price. Some consumers prefer global brands because they enhance their self-image as being cosmopolitan, sophisticated, and modern. Conversely, according to Ger (1999), local brands tend to be targeted and positioned based on a deep cultural understanding and therefore create "a sustainable unique value and offer the symbolism of authenticity and prestige".

The fifth and sixth variables were innovation and brand image. Item I-4 represent innovation and the rest 5-8 were represent brand image. Accordingly on the first variable item 4 "the coverage of mobile signal network is extensive" respondent somewhat supported the idea with the mean of 3.0I. But on items attributes, portability and transmission of data respondents disagreed. This revealed that the extent to which consumers prefer of local made the mobile phone than global brands. Similarly, on the second variable the mean of the statement measuring local phone image ,brand name ,price of good image, and good reputation of brand as a factor with respect brand preference of users have mean values lower than 3 except item. This indicates that most 
of the respondents agreed that these factors affect the brand preference of consumers. The significant value ( $p$-value) for all statements is 0.00 , which is less than 0.05 . This indicates that the statements are statistically significant. So far the $t$-values for all items were greater than the critical value (I.96). In addition this proves that there were significant differences between the two brands on its qualities/ features. So it can be concluded that local brands' innovation and brand image mostly affect the preference of the consumers than global. The obtained results also consistent with the previous studies conducted in different countries. As the research conducted in 2015 highlighted that prefer those smart phones which have advanced features and on their purchase decision is heavily dependent upon these additional features (Kushwaha, 2015). Findings of research also indicated that innovation influences the process of research associated with marketing $\&$ marketing researcher and they also tried to find out the process of adoption of these products (Saaksjarvi, 2003). While the research work of 2012 also emphasized on the importance of innovation and showed that innovation is one of the most influential factor for future use of smart phones and it is contributing up to $34 \%$ in the preference of consumers for future use (Enterprise News, 2012). Research work conducted in the year 2010 explored the association between brand image and customer loyalty by taking reference of customers of Toyota Car and found that that there is a significant relationship between brand image \& loyalty. While the research conducted in 2013 selected one hundred and fifty youngsters as the respondent indicated that there is a significant impact of bran image on brand loyalty (Saeed, Javed \& Lodhi, 20I3). The seventh variable was price of mobile phone. Accordingly the low mean (2.95) found on the first item "I prefer local recognized phone to global since price is cheap. The left three of them were has greater than 3 mean to global made the mobile phone affects the preferences' of consumers. This indicates respondents were agreed as local brand price than that of global. The significant value ( $\mathrm{p}$-value) for all statements is 0.00 , which is less than 0.05. This indicates that the statements are statistically significant. So far the t-values for all items were greater than the critical value (1.96). So it can be concluded that local brands' price affect the preference of the consumers in positive views which implies less consideration to global made brands. Research conducted in order to examine the preference of youth found that the price has no association with the purchase preference of youth \& they mostly pay preference to factors and young consumers are not reluctant in paying more for the enhanced quality and features (Osman, Talib, Sanusi, Shiang \& Alwi, 2012). But the research of 2014 provides conclusive evidence which proves that price is the significant factor for youth and definitely affects the buying preferences as they have limited resources and major source of their income is the pocket money given by their parents. Moreover the research also proves that companies which adapt low pricing strategies without compromising on quality of their offerings became able to create positive influence on the buying behavior of youth (Awan \& Fatima, 20I4).

The last variable was promotion. As a result shows items has less than 3 mean. This indicates more consumers of the local brands disagreed as promotion was influence their preferences. Similarly, the mean of the statement measuring knowledge obtained through advertising, local brand promotions had an impact, word of mouth, catalogue, sales promotion and stronger brand identity of brand as a factor with respect brand preference of users have mean values lower than 3 . This indicates that most of the respondents agreed that these items affect the brand preference of consumers. The significant value ( $\mathrm{p}$-value) for all items is 0.00 , which is less than 0.05 . This shows that the statements are statistically significant. So far the t-values for all items were greater than the critical value (1.96). In addition this proves that there were significant differences between the two brands on its promotion. So it can be concluded that local brands' promotion mostly affect the preference of the consumers than global since less promotional activities regarding to local made mobile phones. Traffic building was achieved by special event promotions like Diwali, Rakshabandhan promotions; inventory reduction through end of season sale; creation and building store image through feature advertising and displays and joint promotions and price image by highlighting the discounts. It helped consumer reduce not only financial risk but also psychological and social risk by making consumer confident of his/her purchase, conformation to group norms by shopping at famous stores/brands and possibility of acquiring well known branded apparel during promotions.

\subsection{Comparison of the Independent Variables}

Table 4.3 Comparison of the Independent Variables

\begin{tabular}{|l|l|l|}
\hline Independent variables & Mean & Rank \\
\hline I. Price & 3.0844 & $\mathrm{I}$ \\
\hline 2. Socials Status & 2.9498 & 2 \\
\hline 3. $\quad$ Country of Origin & 2.9460 & 3 \\
\hline 4. $\quad$ Family And Friends & 2.9000 & 4 \\
\hline $\mathbf{5 .}$ Product Quality & 2.8506 & 5 \\
\hline $6 . \quad$ Brand Image & 2.8409 & 6 \\
\hline 7. $\quad$ Innovation & 2.8318 & 7 \\
\hline $\mathbf{8 .} \quad$ Promotion & 2.6860 & 8 \\
\hline
\end{tabular}

Source: Primaty Data, 2020 
Table 4.3 above shows that the descriptive result of promotion, socials status, country of origin, family and friends, product quality, brand image, innovation and, price according to their impacts on the consumers' local brand preferences. Based on the outcome, price has the highest mean of 3.0844 and then followed by socials status 2.9498 respectively. While promotion, it is the lower mean among these 8 variables which was 2.6860. This implies that majority of the respondents disagreed that promotion plays an important role in influencing consumer behavior towards local brand phone. This result indicates the poor performance of the variables in terms of consumer local brand preferences.

\subsection{Correlation Analysis Results}

Table 4.4. Correlation Analysis Results

\begin{tabular}{|c|c|c|}
\hline & & Independent Variable \\
\hline \multirow{2}{*}{ I. Product Quality } & Pearson Correlation & $.867^{\text {that }}$ \\
\hline & Sig. (2-tailed) & .000 \\
\hline \multirow[t]{2}{*}{ 2. Country of Origin } & Pearson Correlation & $.382^{\text {sta }}$ \\
\hline & Sig. (2-tailed) & .000 \\
\hline \multirow[t]{2}{*}{ 3. Price } & Pearson Correlation & $.288^{* n}$ \\
\hline & Sig. (2-tailed) & .000 \\
\hline \multirow[t]{2}{*}{ 4. Social Status } & Pearson Correlation & $.683^{\text {sht }}$ \\
\hline & Sig. (2-tailed) & .000 \\
\hline \multirow[t]{2}{*}{ 5. Family And Friends } & Pearson Correlation & $.837^{\text {tht }}$ \\
\hline & Sig. (2-tailed) & .000 \\
\hline \multirow[t]{2}{*}{ 6. Innovation } & Pearson Correlation & $.250^{\text {sts }}$ \\
\hline & Sig. (2-tailed) & .000 \\
\hline \multirow{2}{*}{ 7. Brand Image } & Pearson Correlation & $.648^{\text {thin }}$ \\
\hline & Sig. (2-tailed) & .000 \\
\hline \multirow[t]{2}{*}{ 8. Promotion } & Pearson Correlation & $.75 I^{\text {sta }}$ \\
\hline & Sig. (2-tailed) & .000 \\
\hline \multicolumn{3}{|c|}{ Correlation is significant at the 0.0I level (2-tailed). } \\
\hline
\end{tabular}

Source: Primary Data, 2020

Correlation is a statistical measure of the co variation, or association, between two variables (Zikumund, 2003). Its purpose is to determine the relationship of one variable to another. Correlation coefficient $(\mathrm{r})$ is within the range of +1.0 to $-I .0$. If the value of $\mathrm{r}$ is more than 0 to I.0, means there is a positive linear relationship, similar to if the value is less than 0 to -0.1 , means it has a negative linear relationship. If the value of $\mathrm{r}$ is at 1.0 or -I.0, there is a perfect positive or negative linear relationship. However there is no correlation is indicated if $r=0$. This method is used in this study to test the relationship between the independent variables which are friends and family, social influence, product features and branding and the dependent variable which is purchasing behavior. To determine the relationship between independent variables (promotion, socials status, country of origin, family and friends, product quality, brand image, innovation and, price) and brand preference was computed. Table 4.4, presents the results of Pearson correlation on the relationship between independent variables and brand preference. Pearson correlation analysis is a measure of the strength of linear relationship between independent variables and dependent variable. Based on table 4.4, correlation of each independent variable were significant at 0.01 levels or 0.05 levels (2-tailed). Accordingly, product feature have strongest significant relationship with brand preferences, followed by family and friends and promotion.

\subsection{Multiple Regression Results}

Multiple regression analysis is a method to analysis the effects of two or more independent variables on a single interval-scaled dependent variable are investigated simultaneously (Zikmund, 2003). For this particular study, this method is used to determine the relations between 8 independent variable (friends and family, social influence, product features and branding) on a single dependent variable. In this study, multiple regression analysis was carried out to get the predictive values of the constructs considered. Since the model is developed in such a way that each construct is being affected by other constructs, it is neces sary to carry out a separate regression analysis against each variable which are considered to be affected by other variables. This was basically made to determine the linear combination of the constructs. 
Table 4.5: Model Summary

Model Summary

\begin{tabular}{|l|l|l|l|l|}
\hline Model & R & R Square & Adjusted R Square & Std. Error of the Estimate \\
\hline I & $.942^{\mathrm{a}}$ & .887 & .885 & $.1377 \mathrm{I}$ \\
\hline
\end{tabular}

a. Predictors: (Constant), PROMO, Country Of Origin, Innovation, Brand Image, Family And friends, price, Socials Status, Product quality

Source: Primary Data, 2020

In the table 4.5 on the model summary it was observed that the coefficient of determination or the $\mathrm{R}$ square change was .887 which indicates that $88.7 \%$ of the variance is explained by the stated independent variables on the dependent variable which is consumer brand preferences and the remaining II.3\% is predicted by others. From the linear equation, it revealed that there is a significant positive relationship between (product quality, country of origin, family and friends, innovation, brand image and promotion) and dependent variables. But, negative relationship was observed between price, social status and dependent variable. The product features/quality has the most significant influence on purchasing behavior. It has proven by the coefficient value $\beta=.344$. It could be explained by a unit increases in product features enable an increase of .344 unit in purchasing preference of consumers. This shows the product features is a more predictor of consumer preference on to purchase local brand than other 7 independent variables.

Table 4.6: Multiple Regression Results

\begin{tabular}{|c|c|c|c|c|c|c|}
\hline \multicolumn{7}{|c|}{ Coefficients $^{a}$} \\
\hline & & \multicolumn{2}{|c|}{$\begin{array}{l}\text { Unstandardized } \\
\text { Coefficients }\end{array}$} & \multirow{2}{*}{$\begin{array}{l}\text { Standardized } \\
\text { Coefficients } \\
\text { Beta } \\
\end{array}$} & \multirow[b]{2}{*}{$\mathrm{t}$} & \multirow[b]{2}{*}{ Sig. } \\
\hline \multicolumn{2}{|c|}{ Model } & $\mathrm{B}$ & Std. Error & & & \\
\hline \multirow[t]{9}{*}{$\mathrm{I}$} & (Constant) & .012 & .066 & & .179 & .858 \\
\hline & I. $\quad$ Product Quality & .344 & .042 & .387 & 8.198 & .000 \\
\hline & 2. Country Of Origin & .237 & .014 & $.29 \mathrm{I}$ & 16.407 & .000 \\
\hline & 3. $\quad$ Price & -.017 & .018 & -.026 & -.976 & .330 \\
\hline & 4. Social Status & -.033 & .024 & -.045 & -1.382 & .168 \\
\hline & 5. Family and Friends & .264 & .033 & .316 & 8.000 & .000 \\
\hline & 6. Innovation & .001 & .016 & .002 & .066 & .948 \\
\hline & 7. $\quad$ Brand Image & .073 & .018 & .124 & $4.10 \mathrm{I}$ & .000 \\
\hline & 8. Promotion & .157 & .024 & .178 & 6.626 & .000 \\
\hline
\end{tabular}

Source: Primary Data, 2020

Tables 4.6, present the results from the multiple regressions carried out using the 8 independent variables as the independent variables and brand preference as the dependent variable.

Based on the output of the table 4.6, the following equation is formed:

$$
\begin{aligned}
& \mathrm{CBP}=\alpha+\beta_{I} X_{I}+\beta_{2} X_{2}+\beta_{3} X_{3}+\beta_{4} X_{4}+\beta_{5} X_{5}+\beta_{6} X_{6}+\beta_{7} X_{7}+\beta_{8} X_{8}++\mathcal{E} \\
& \mathrm{CLBP}=.0 \mathrm{I} 2+.344 X_{I}+.237 X_{2}+-.017 X_{3}+-.033 X_{4}+.264 X_{5}+.001 X_{6}+.073 X_{7}+.157 X_{8}++\mathcal{E}
\end{aligned}
$$

However, there is a negative relationship between price and social status with BP as its coefficient value $\beta=-.017$ and $\beta=-.033$ respectively. It will cause a unit increases in price and social status enable a decrease of .0I7 and .033 unit in preference to purchase local brands. Moreover, from the findings of this study, researcher found out that not all of the independent variables have positive effects on brand preference. The findings of this study also indicated that quality is the most important factor to have positive and significant effect on brand preference, followed by family and friends, and country of origin.

\section{Conclusion and Recommendations}

\section{I. Conclusion}

In today's competitive and dynamic world of communication industry, customer is considered as a valuable capital for service and physical product providing industry. In this regard the responses $\backslash$ preferences of customers have a determining effect on survival and success of organizations. Hence, in this study the influence of factors on consumer preference were investigated. Studied dimensions of customer response include promotion, socials status, country of origin, family and friends, product quality, brand image, innovation and, price. Based on the findings the study can be concluded as below: 
- The results of the descriptive analysis indicated that, almost low responses were obtained. This was supported by the ttest results, which showed that a significant relationship existed between factors affecting and the mobile phone brand preferences. This implies that consumers have low preferences towards local made mobile brands. This proves that consumers mostly affected by factors affecting (promotion, socials status, country of origin, family and friends, product quality, brand image, innovation and, price) consumer preference.

- The results of correlation furthermore revealed that a positive significant relationship between the mobile phone brand preferences and determinants. The results implied that consumers considered as important factors, because considering these assisted in determining the brands of they chose. Then this implies that consumer less considers as criteria for the mobile phone brand selections for local brands.

- The obtained results of the regression analysis confirm that there is no co linearity among variables and $88.7 \%$ of the explored variables explained the dependent variable where II.3\% remained unexplored. This indicates that strong relationship between dependent and independent variables. Then this result also implies that the impacts of factors on the consumers local brand presences.

\subsection{Recommendations}

- Based on the findings and conclusions of the study, the researcher forwards the following recommendations to the local mobile producers Company and suggestion for other researchers.

- The finding of the study indicates high relationship between determinants and consumer preference and also as per the descriptive results consumers were disagreed as the factors satisfy the criteria needed to influence their behavior to purchase local brands therefore, the company should maintain the following in order to have persistent consumer in today's world.

- Marketers should keep and innovate brand value by satisfying desire of consumers, charging fair price, being available, providing comfort, durability and self-esteem.

- Brand characteristic of the company by keeping and innovating the logo of the company, usage quality, and use word of mouth publicity, good brand name and attractive advertisement.

- In order to have a sustainable association the company should be strong in maintaining to work on that the consumer have a good memory recall, reminding of special events, being different among others, having sensational feeling, being attached and obsessive.

- Also manufacture need to understand consumer variables such as the influence of friends, their attention to brand names, and their stickiness to certain brands so that it is possible to develop effective branding strategies that heavily influence the preference of young and middle age groups .

- Also the promotion of manufacturers should be tailored to specific customer's focus on the audiences', comfort, quality, price, brand, and country of origin.

\section{References}

Aaker, D., 1996, Measuring Brand Equity across Products and Markets.

Agbonifoh, B. A., \& Elimimian, J. U. (I999). Attitudes of developing countries towards country-of-origin products in an era of multiple brands, Journal of International Consumer Marketing, II(4), 97-II6.

Albanese, J.S. (1987): The nature of preferences: An exploration of the relationship between economics and psychology, Journal of Economic Psychology, 8(I), 3-I8.

Alden, D.L., Steenkamp, J.E.M. and Batra, R. (1999), "Brand Positioning through advertising in Asia, North America and Europe: the role of global consumer culture”, Journal of Marketing, Vol. 63, pp.75-87.

Arif, Hajra., Ahmed, Shahbaz. \& Farrukh, Muhammad., (2015), "Factors Affecting Customer's Preferences to Buy Cellular Phone for Local versus International Brands: A Case Study in Pakistan” Journal of Marketing and Consumer Research, I0, I, III-II9

Asch, S.E. (I95I),”Effects of group pressure upon the modification and distortion of judgments”, Asch, S.E. and Guetzkow, H. (eds.), Carnegie, Pittsburgh

Awan. Abdul Ghafoor \& Fatima, Arooj, (2014), "Impact of marketing strategies on youth purchasing behavior: A Case study of the mobile phone industry” British Journal of Marketing Studies.2, 4, 72-80

Awan. Abdul Ghafoor \& Fatima, Arooj, (2014), "Impact of marketing strategies on youth purchasing behavior: A Case study of the mobile phone industry" British Journal of Marketing Studies.2, 4, 72-80

Batra, R., Lehmann, D.R. and Singh, D. (1992). The brand personality component of brand goodwill: Some antecedents and consequences, In Aaker, D. A. and Biel, A. L., Brand Equity and Advertising: Advertising's role in Building Strong Brands, 83-96, Hillsdale, NJ: Erlbaum.

Bhukya, B. and Singh, S. 2013. Brand preference of students towards choosing cellular service providers in Hyderabad city. Asian Pacific Journal of Marketing and Management Review, 2(5):I-20. 
Bilkey, W.J. and Nes, E. (I982), "Country-of-origin effects on product evaluations”, Journal of International Business Studies, Volume I3, pp. 89-99.

Comer and T. A. Wikle (2008), Worldwide diffusion of the cellular telephone, (1995-2005). The Professional Geographer, 60(2), 252-269.

Corsby, Philip B. (1979), Quality Is Free: The Art of Making Quality Certain, New York: New American Library.

Dadzie, A. and Boachie-Mensah, F. 20II. Brand preference for the mobile phone operator services in the Cape Coast Metropolis. International Journal of Business Management, 6(II): I90-205.

Dawar, N. and Parker, P. (I994), "Marketing universals: consumer's use of brand name, price, physical appearance, and retailer reputation as signals of product quality", Journal of Marketing, Vol. 58, pp.8I-95.

DeSabro, W.S., Young, M.R. and Rangaswamy, A. (1997). A parametric multidimensional unfolding procedure for incomplete non-metric preference/choice set data in marketing research, Journal of Marketing Research, 34(4), 499-5I6.

Domie, S. (2013), "Assessing the Factors Influencing Consumer Switch from Local to Imported Products: A case study of Kasapreko Company Limited-Ghana”, Business Economics and Tourism.

Domzal, T. and Ugner, L.S. (I987), "Emerging positioning strategies in global marketing", The Journal of Consumer Marketing, Vol. 4 (4), fall, pp.23-40.

Douglas. B, John. A, Quelch, and Taylor. E, (I987), "How Global Brands Compete”, Harvard Business Review

Durrani, Baseer Ali., Godil, Danish Iqbal., Baig, Mirza Uzair \& Sajid, Sana., (2015), "Impact of brand image on buying behaviour among teenagers” European Scientific Journal, II, 5, I55-168

Elliott, G. R., \& Cameron, R. C. (I994).Consumer perception of product quality and the country-

oforigin effect.Journal of International Marketing, 49-62.

Faure, C. and Natter, M. (2010). New metrics for evaluating preference maps, International Journal of Research in Marketing, $27(3), 261-270$.

Ger, Guliz (1999), "Localizing in the Global Village: Local Firms Competing in the Global Village: Local Firms Competing in Global Markets," California Management Review, 4I,

Ger, G., \& Belk, R. W. (I993). I'd like to buy the world a coke: Consumptionscapes of the "less affluent world”. Journal of Consumer Policy, I9(3), 27I-304.

Hamzaoui, L., \& Merunka, D. (2006). The impact of country of design and country of manufacture on consumer perceptions of bi-national products quality: An empirical model based on the concept of fit. Journal of Consumer Marketing, 23(3), I45-I55.

Hansen L. Service layer essential for future success. Ericsson Mobility World, General article. 2003. available at: http://www.ericsson.com/mobilityworld/sub/ articles/other articles/nl03jun05

Hansen, F. and Christensen, S.R. (2007). Emotions, Advertising and Consumer choice, Copenhagen Business School Press.

Henderson, R. 20I2. Industry employment and output projections to 2020.2 Available: http://www.bls.gov/opub/mlr/2012/0I/art4full.pdf (Accessed 27 April 2015).

Holt, Douglas, Quelch, J., Taylor. E, (2003), "Managing the Transnational Brand: How Global Perceptions Drive Value," working paper, Harvard Business School.

Hossein, R. D. and Hamed, D. 2012. Comparative study effect of culture from Hofstede perspective on purchasing the mobile phone in Iran and Thailand society. International Journal of Business and Social Science, 3(6): I46-I54.

J. Marumba, "A Pragmatic Assesment of the Determinants of Consumer Brand Prefernce in the Mobile Telecommunication Services Market in Masvingo Urban” Zimbabwe, Management and Administrative Science Review, 2(2), 2013 , I44I55.

Johansson. K, and Ronakainen. I (2005), “The esteem of Global Brands”, Brand Management,Vol. I2, No. 5, p. $339-354$.

Jordan, P.W. (I998), "Human factors for pleasure in product use”, Applied Ergonomics, Vol. 29, No. I, pp. 25-33

K. G. Singh, "Customer Preferences and Satisfaction towards Mobile Phone- The Case of Selected District of Punjab", Asian Journal of Research Marketing, I(4), 2012, I6-3I.

K. G. Singh, "Customer Preferences and Satisfaction towards Mobile Phone- The Case of Selected District of Punjab", Asian Journal of Research Marketing, I(4), 20I2, I6-3I.

Kapferer, J.N. (1997) Strategic Brand Management, 2nd edn, Kogan Page: Dover, NH.

Karjaluoto, H., Karvonen, J., Kesti, M., Koivumaki, T., Manninen, M., Pakola, J., Ristola, A. and Salo, J. 2005. Factors affecting consumer choice of mobile phones: Two studies from Finland. Journal of Euro marketing, I4(3): 59-82.

Khan, Shahzad \& Rohi, Sobia, (2013), "Investigating the factors affecting youth brand Choice for mobile Phones Purchase - A study of Private universities students of Peshawar” Management \& Marketing Challenges for the Knowledge Society, $8,2,369-384$

Kirmani, A. and Baumgartner, H. (2000), “Reference Points Used in Quality and Value Judgments”, Marketing Letters, Vol. II (4), pp. 299-3I0. 
Kotler (2005) uttered that marketers are very much interested to study demographic environment of market in a view that it involves people and people make up market.

Kotler, P. and Armstrong, S. (I989), "Principles of Marketing", Prentice-Hall, Englewood Cliffs, NJ

Kushwaha, Bijay Prasad., (20I5), "An empirical study on youth perceptions and preferences on smart phones” International Journal of Research in IT \& Management, 5, I0, 82-90

Lewis, Robert C. and Bernard H. Booms (I983), "The Marketing Aspects of Service Quality,” in Emerging Perspectives on Services Marketing

Li, S., \& Li, Y. (2010). An Exploration of the Psychological Factors Influencing College Students' Consumption of The mobile phone in West China. International Journal of Business and Management, 5(9), PI32.

Liu, C.M. (2002), "The effects of promotional activities on brand decision in the cellular telephone industry", Journal of Product and Brand Management, Vol. I I, No. I, pp. 42-5I.

M Chowdhury and M. T. Rahman, "Consumer Attitude towards the Cell Phone; A Study on Young Generations of Chittagong Metropolitan city, Bangladesh”, Asian Business Review, 3(5), 2013, I6-20.

M. Sata, "Factors Affecting Consumer Buying Behaviour of Mobile Phone", Mediterranean Journal of Social Science, 4 (I2), 2013, I03-II2.

Macro Analysis \& Consumer Research Organization (2004). Study of The mobile phone Usage among the Teenagers And Youth In Mumbai. Retrieved from, https://www.itu.int/osg/spu/ni/futuremobile/socialaspects/IndiaMacroMobileYouthStudy04.pdf.

Malik, Muhammad Ehsan., Ghafoor, Muhammad Mudasar., Iqbal, Kashif., Qasim Ali, Hira Hunbal, Muhammad Noman and Bilal Ahmad. (2013), "Impact of brand image and advertisement on consumer buying behavior", World Applied Sciences Journal, 23, I, I I7-I22

March, J.M. (1978). Bounded rationality, ambiguity, and the engineering of choice, Journal of Economics, 9(2), 587-608.

McCarthy, J. and Perreault, W. (I984). Basic Marketing 8th, ed

McCracken, G. (I986), "Culture and Consumption: A Theoretical account of the structure and movement of the cultural meaning of consumer goods”, Journal of Consumer Research, Vol. I3, pp. 7I-84.

McDaniel, C., Lamb, C. W., and Hair, J. F. 20I4. Marketing Essentials. 7th ed. Cape Town: Oxford University Press.

Meyer, R.J. and Kahn, B.E. (I99I), "Probabilistic Models of Consumer Choice Behavior" in Handbook of Consumer Behavior, Robertson, T.S. and. Kassarjian, H.H, (eds.), Englewood Cliffs,. Prentice Hall, N.J.

Mokhlis, S. and Yaakop, A. Y. 2012. Consumer Choice Criteria in The mobile phone Selection: An Investigation of Malaysian University Students. International Review of Social Sciences and Humanities, 2(2): 203-2I2.

Mokhlis, S. and Yaakop, Y.A. (20I2), "Consumer Choice Criteria in The mobile phone Selection: An Investigation of Malaysian University Students” International Review of Social Sciences and Humanities, Vol. 2, No. 2, pp. $203-212$

Nguyen, T., Barrett, N., Miller, K., 2005. Perceived Brand Globalness: Antecedents and Out-come - The Case of Vietnamese Consumers. Proceedings of the 34th EMAC Conference, 24-27 Mai 2005, Università Commerciale Luigi Bocconi, Milan, Italy.

Nilson, H. (1998), "Competitive Branding-Winning the Marketplace with Value Added Brands”, John Wiley, New York

Oliver, R.L. and Swan, J.E. (1989). Consumer Perceptions of Interpersonal Equity and Satisfaction in Transactions: A Field Survey Approach, Journal of Marketing, 53 (April), 2I-35.

Opoku, R.A., \& Akorli, P.A.K. (2009). The preference gap: Ghanaian consumers ${ }^{e e}$ attitudes toward local and imported products. African Journal of Business Management, 3(8), 350-357.

Osman, M.A; Talib, A.Z.; Sanusi, Z.A; Shiang-Yen, T. and Alwi, A.S. (2012), A Study of the Trend of Smartphone and its Usage Behavior in Malaysia, International Journal on New Computer Architectures and Their Applications, 2(I), 275-286

P Gopal, Anjali and Aakanksha, "Mobile Marketing Research: A Study of Brand Prefrence by VIT Student's", International Journal of Advanced Research in Computer Science and Software Engineering, I I, 2013, I620-I623.

Peterson, R.A. and Jolibert, A.J.P (I995), "A meta-analysis pf country-of-origin effects”, Journal of International Business Studies, Vol. 26 (4), pp. 883-900.

Petruzzellis, L. 20I0. The mobile phone choice: Technology versus Marketing. The brand effect in Italian market. European Journal of Marketing, 44(5): 610-634. Available: www.emaraldinsight.com.dutlib.dut.ac.za/doi/ref/ IO.II08I0309056I0I 103298 (Accessed 7 March 2015).

Pikturnienè, I. (2013), “Attitude Formation Towards Local And International Ecological Face And Body Care Brands Among Lithuanian Female Consumers”, Organizations And Markets In Emerging Economies, 4, I

Quelch, J. (I999), Global brands: taking stock”, Business Strategy Review, Vol.IO (I), pp.I -I4.

R. Rijial, "Brand preference on Mobile Purchase among the Students of Roskilde University", Bechelor of Business studies Project report, Roskilde University. 
S. Malviya, M. S. Saluja and A. S. Thakur, "A Study of the Factors Influencing Consumer's Purchase Decision towards Smartphones in Indore”. International Journal of Advanced Research in Computer Science and Management Studies, $\mathrm{I}(6), 20 \mathrm{I} 3, \mathrm{I} 4-2 \mathrm{I}$.

S. Mokhlis and A. Y. Yakoop, "Consumer Choice criteria in The mobile phone selection: An investigation of Malaysian University student”, International review of Social Science \& Humanities, 2(2), 2012, 203-212.

Saaksjarvi, Maria, (2003), "Consumer adoption of technological innovations” European Journal of Innovation Management 6. 2. $90-100$

Saeed, Rashid., Javed, Sara. \& Lodhi, Rab Nawaz, (2013), "Empirical Study of Factors Affecting Brand Loyalty: Evidence from Fast Food Restaurants in Pakistan” Journal of Basic and Applied Scientific Research, 3, I2, 46-55

Saffu, K., \& Walker, J. (2006). The country-of-origin effects and consumer attitudes to buy local campaign. The Ghanaian case. Journal African Business, 7(I/2), I83-199.

Samuels, W.J. (1978). Information systems, preferences, and the economy in the JEI, Journal of Economic Issues, I2(I), 2341 .

Sardar, Ramesh, (2012), “ Brand Preference of Passenger Cars in Aurangabad District”, International Journal of Multidisciplinary Research, 2, 3, pp 43I-442

Schiffman, L. G. and Kanuk, L. L. 2010. Consumer Behaviour. IOth ed. New Jersey: Pearson Prentice-Hall.

Schuiling, Isabelle and Jean- Noel Kapferer (2004), "Real Differences between Local and International Brands: Strategic Implications for International Marketers, "Journal of International Marketing, Vol.I2 (4), 97-II2.

Shahzad, K. and Sobia, R. 2013. Investigating the factors affecting youth brand choice for mobile phones purchasing - A study of private universities students of Peshawar. Management and Marketing Challenges for the Knowledge Society, 8(2): 369-384.

Shocker, Allan D., Rajendra K. Srivastava, and Robert W. Ruekert (I994), "Challenges and Opportunities Facing Brand Manage ment: An Introduction to the Spe

Steenkamp, J.E.M., Batra, R. and Alden, D.L. (2003), "How perceived brand globalness creates brand value", Journal of International Business Studies, Vol. 34 (I), pp. 53-65.

Suki, N.M. and N.M. Suki, (2013), "Dependency on Smartphone: An analysis of structural equation modeling". Jurnal Teknologi, 62, I, 49-55

Tomer, J.F. (I996). Good habits and bad habits: A new age socio-economic model of preference formation, Journal of SocioEconomics, 25(6), 619-638.

Tornatzky, L.G. and Klein, K.J. (I982), "Innovation Characteristics and Innovation Adoption- Implementation: A MetaAnalysis of Finding”, IEEE Transactions on Engineering Management, Vol. 29, No. I, pp. 28-45

Upadhyay, Payal \& Joshi, Jayesh, (20I4) "Impact of Advertising on Buying Behavior of Youth in Kota City with Special Reference to Branded Outfits” International Journal of Managerial Studies and Research, 2, 2, I-20

Usunier, J. (2006). Relevance of business research: The case of country-of-origin research in marketing. European Management Review, 3(I), 60-73.

Wolfe, Alan (I99I), "The Single European Market: National of Euro- Brands," International Journal of Advertising, I0 (I), 9-58.

Zajonc, R.B. and Markus, H. (1982), Affective and cognitive factors in preferences, Journal of Consumer Research, 9(2), I23I3I.

Zeithaml, 1988 and Rowley, I998Challenges and opportunities facing brand management: an introduction to the special issue. J. Marketing Res., 3I(2), pp. I49-I58.

\section{Copyrights}

Copyright for this article is retained by the author(s), with first publication rights granted to the journal. This is an open-access article distributed under the terms and conditions of the Creative Commons Attribution license (http://creativecommons.org/licenses/by/4.0/). 